\title{
WITH AN ORCHESTRA OR SOLO? NORWID IN THE PARIS STUDIO OF JULIUSZ KOSSAK
}

In 2015, the National Museum in Warsaw ${ }^{1}$ bought a humorous drawing by Juliusz Kossak titled Orkiestra artystów [An Orchestra of Artists], which presents a group of Polish painters active around the middle of the nineteenth century in Paris (fig. 1). This picture was published in 1900 in the classic monograph by Stanisław Witkiewicz, making it well known among those interested in Kossak's art, and rekindling the interest of scholars in it. This was largely due to the accompanying anonymous hand-written note containing information that helps to identify the persons shown in the scene, which was associated with an anecdote related by Witkiewicz (see the annex). First of all, however, let us turn to the note:

In 1856, apart from Kossak, those who lived in Paris included Rodakowski, Kapliński, Tepa, Chlebowski, Straszyński, and others. Kossak convinced them to send their paintings to Warsaw. Later, people would look in Warsaw papers for some mention of them but could not find anything, and one person who read a longer article on the orchestra of Bilse reproached Kossak for this half-humorously. In response, Kossak advised the entire colony to form an orchestra, which he immediately sketched: Rodakowski playing the cello, Kapliński, a painter and poet, on the harp, Tepa, who just returned from a trip to the East and is wearing a fez on tam-tam - everyone, including the model who is wielding a hurdy-gurdy, is seen playing various instruments symbolizing their individual attributes. On the shelf stands a bust of Delacroix, with a hat covering his eyes, while Ingres is buried under piles of paper, and the head of Kątski, adorned with laurels, looks from the plinth. ${ }^{2}$

${ }^{1}$ Hereinafter referred to in abbreviated form as MNW.

${ }^{2}$ S. Witkiewicz, Juliusz Kossak, Warszawa 1900, p. 62. The drawing is reproduced there as well. 


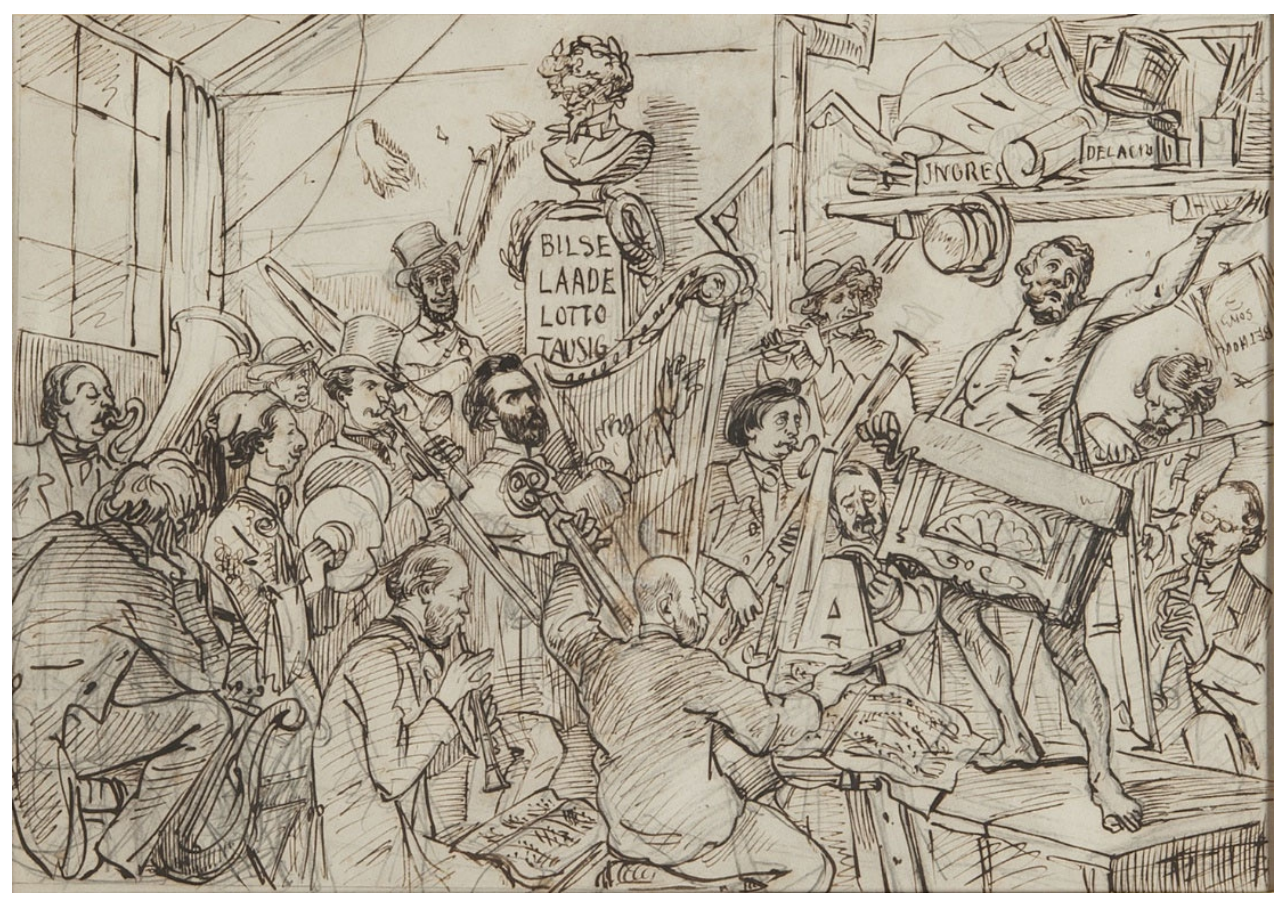

Fig. 1. Juliusz Kossak, Orkiestra artystów, 1857-1860

Witkiewicz introduces only three members of this astounding orchestra, but thanks to hints left in the aforementioned note (see the annex) we can establish the identity of others: Juliusz Kossak, who is playing the trombone, Tadeusz Gorecki on bassoon, Franciszek Faliński (wearing glasses) on flute (or rather clarinet or oboe). According to Anna Grochala from the Etchings and Drawings Cabinet at the National Museum in Warsaw, Stanisław Chlebowski, who is mentioned in the anecdote, "closely resembles the standing man with a top hat, who is looking at the orchestra"; the man standing next to him is most probably Leonard Straszyński. ${ }^{3}$ Among those portrayed there is also Teofil Kwiatkowski, who is sitting next to Tadeusz Gorecki. The plinth supporting the sculpture of the violinist Apolinary Kątski features names of famous conductors and soloists: “[Benjamin] Bilse, [Friedrich, Lebrecht, and Rudolf] Laade, [Izydor] Lotto and

3 A. Grochala, Juliusz Kossak jako karykaturzysta, "Spotkania z Zabytkami" 2016, no. 11-12, p. 54. See also Grochala's commentary on this drawing at the museum's website: http:// cyfrowe.mnw.art.pl/dmuseion/docmetadata?id=35102\&show_nav=true (accessed 21 September 2018). 
[Karol] Tausig." ${ }^{.4}$ It is not known when exactly the drawing was done. According to Witkiewicz it dates back to 1856 . The note attached to the drawing mentions the years 1855-1860, while Anna Grochala, who analysed the schedule of orchestral performances in Warsaw and the biographies of authors, concluded that the drawing could have been made somewhere between 1857 (the first performance of Bilse's orchestra in Warsaw) and the beginning of 1861 (when Chlebowski probably arrived in Paris, while Kossak returned to Warsaw). ${ }^{5}$ Given the fact that the author of Orkiestra artystów came to Warsaw on 27 February 1861, this time bracket should be narrowed down to the years 1857-1860.

The note attached to the drawing mentions yet another member of this musical circle - Cyprian Norwid, who was "already quite deaf at the time and was sitting nearby, listening attentively." Kossak depicted him with his back turned to the viewers, in the bottom left-hand corner of the work. Focused and holding a hand next to his ear, Norwid is listening to music, while his instrument - the lyre - is resting at his feet. Thanks to the anonymous comment we learn something that would otherwise pose a huge challenge given the pose assumed by the figure, whose face remains hidden from viewers. Out of due caution we should raise the question whether we can actually verify the proposed identification of the man with the lyre as Norwid. Nevertheless, such doubts wane if we take into account that although Kossak placed Norwid with his back turned to us, he did not strip his figure of any individual characteristics. He emphasized his problems with hearing, as noted by the anonymous commentator, and Norwid's attempts to cope by placing a specially formed hand to his ear and leaning towards the source of sound.

As some may recall, Norwid became hard of hearing due to an infection he caught in 1846 when he was imprisoned in Berlin. The problem exacerbated with time and made his contacts with others increasingly difficult. He often touched upon this in his letters to friends and acquaintances. In 1862 he wrote to Father Karol Kaczanowski: "My ears are something that I value low because what is their use if they are deaf?" (DW XII, 51), and several years later to Karol Ruprecht: "I lost my hearing in a damp prison" (PWsz IX, 214). In 1875 he explained to

${ }^{4}$ Grochala briefly discusses the Warsaw concerts of the aforementioned musicians in the period related to Kossak's anecdote in Juliusz Kossak jako karykaturzysta, p. 54.

${ }^{5}$ Ibid. See also: http://cyfrowe.mnw.art.pl/dmuseion/docmetadata?id=35102\&show_ nav $=$ true (accessed 21 September 2018). Although the author of the monograph about Stanisław Chlebowski argues that the painter arrived in Paris in the first half of 1861 (the earliest confirmation of his stay in Paris is a drawing signed "26 V 1861 Paryż"), it is impossible to entirely exclude an earlier visit, possibly made between 1859 and 1861 (the painter was travelling around Europe at the time). See: A. WóJciK, Stanistaw Chlebowski, „Nadworny Farbiarz Jego Sultańskiej Mości”. Życie i twórczość, Warszawa 2016, pp. 32-33. 
Władysław Chodźkiewicz: "it is mostly on days when the weather is very nice that I can hear - I have adopted treatment and probably will hear again (in the years 46-8 I began to suffer from this condition in a Berlin prison, and it lasts to this day)" (PWsz X, 37). As confirmation, two opinions of other people regarding this issue can be quoted, both from the second half of the 1850 s, i.e. the time when Kossak drew the caricature. In 1856 Major Józef Zaleski wrote that "Cyprian looks good but is deaf as a doornail" (PWsz XI, 480), while three years later Andrzej Edward Koźmian wrote in a letter to his family that the poet "is almost completely deaf" (PWsz XI, 482).

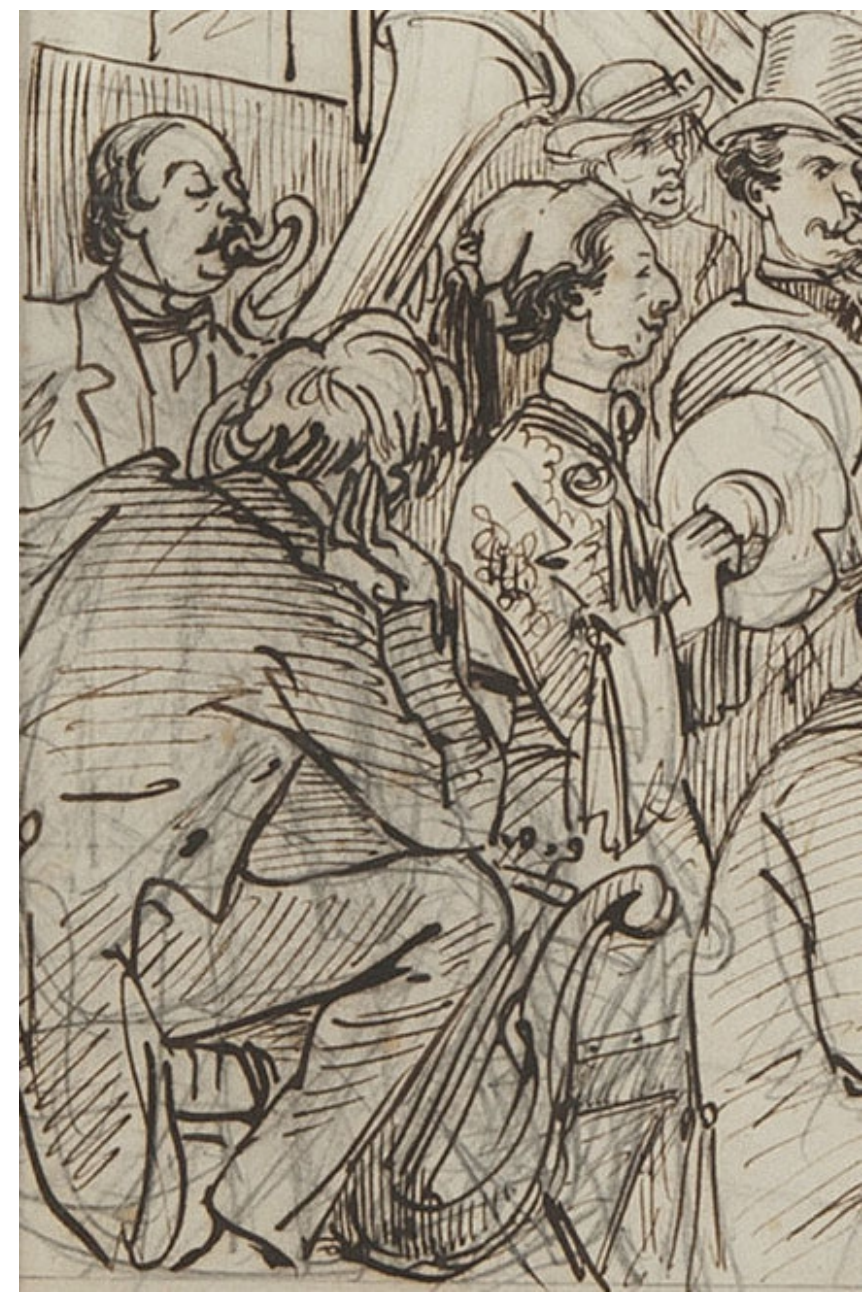

Fig. 2. Juliusz Kossak, Orkiestra artystów, close-up (C. Norwid in the foreground on the left). 
Memory about Norwid's ailment was also preserved for many years in the Kossak family, traces of which can be found on the pages of the first volume of Dziedzictwo [Heritage] written by Juliusz Kossak's granddaughter Zofia. The three-volume work is most often described as historical prose or a social novel of manners, but some also regard it as an epic, a national treatise, a family apocryphal work, a family saga, or a fictionalized biography of the Kossak family. ${ }^{6}$ Setting out to compose this work, Zofia Kossak wrote to Jan Dobraczyński: "I have returned to writing several months ago and work in spare moments on a large-scale memoir that is thoroughly authentic. The first volume (out of a predicted total of three or four) will be published towards the end of this year, God help." The book, which is based on family sources and documents, is not free from mistakes and diverges from preserved materials, which were used chiefly as literary fuel. Hence the somewhat justified yet rather harsh assessment by Maciej Masłowski, who argues in a monograph devoted to the painter that Dziedzictwo is a "fairy tale, graciously staged but entirely untrue and fabricated." Still, even if we agree that it cannot be regarded as an unquestionable source of biographical information, it is possible to acknowledge the liveliness and relative accuracy of Juliusz Kossak's reminiscences of Norwid.

Mention of the poet's problems with hearing appears already in the account of the first meeting between the poet and the recently married Juliusz and Zofia Kossak, which is rendered (just like the entire report from the Paris period) as a letter from Zofia to her father Wojciech Gałczyński. This allegedly accidental meeting occurred in a Paris restaurant serving Polish dishes. Upon hearing people speaking Polish Norwid approached the couple, asking when they arrived. As we learn, they had come to Paris three days before from Siąszyc. Norwid obviously could not hear well and would put his hand to his ear, asking them to repeat. He then introduced himself and continued the conversation with his hand by his ear. Juliusz, on the other hand, "drew a notebook from his pocket and began to sketch Mr Norwid on his knee, later claiming that he had a very interesting face.""

Returning to Orkiestra artystów, it should be noted that the characteristic of Norwid is complemented with the lyre that accompanies him, which - in

6 J. Mrożek-Myszkowska, ,Dziedzictwo” Zofii Kossak-próba monografii, Toruń 2012, p. 21. A lot of information is also contained in the chapter Dziedzictwo Zofii Kossak-zagadnienie gatunku (pp. 147-171).

7 After: J. Dobraczyński, Opowieść o Juliuszu i Zofii, [in:] IDEM, Wielkość i świętość. Eseje, Warszawa 1958, p. 280.

${ }^{8}$ M. MasŁowski, Juliusz Kossak, Warszawa 1984, p. 30.

9 Z. KossaK, Dziedzictwo, cz. 1, Warszawa 1961, pp. 121-122. No portrait of Norwid by Kossak is known to exist. 
accordance with Kossak's intention to make every instrument refer to specific features of the portrayed figures - indicates that Norwid is a poet, and gestures, through references to poetry and antique music, to the biblical figure of David and the mythological Arion, who symbolize art, craftsmanship, grandeur, and accomplishment. Norwid's attribute should be connected - it seems - not only with the kind of art he practiced but also with his aesthetic position, especially his views on the nature of art and the duties of artists. It is possible that the presence of the lyre is connected with the famous debate sparked in artistic circles by the 1857 article Sztuka polska [Polish Art] written by Julian Klaczko for the Parisian journal Wiadomości Polskie. This debate has been extensively covered in scholarly literature, both in the history of art and in Norwid studies, especially in works addressing the dialogue between Klaczko and Norwid. ${ }^{10}$ At this point it also seems apt to note the temporal coincidence of this debate and Kossak's caricature in the context of Norwid's views expressed in $O$ sztuce (dla Polaków) [On Art (for Poles)], where the poet opposed Klaczko, probably after conversations with artist friends. The memoir by Wojciech Gerson, who stayed in Paris between December 1856 and early 1858, contains a telling account of these talks:

[...] while travelling abroad to complete my art studies I set out to examine whether it is possible (and if so, then to what extent) to reconcile practicing art with duties to the motherland. Developed artistic life in the West was supposed to help me with answering this question. Exploring the conditions of artistic creativity by visiting excellent art collections, studying at the atelier of Cognet, partaking in discussions about aesthetics with one of the best educated Poles in this area who stayed in Paris at the time, Cyprian Norwid, and taking strolls along Paris boulevards and in the symbolic Elysian Fields - all of this confirmed my earlier intuitions. These convictions in turn served as the theoretical grounds for a polemic against Klaczko's text in Café de Régence [...]. ${ }^{11}$

Although Gerson did not become a member of Kossak's orchestra (perhaps he was no longer in Paris when the drawing was done), it is known from other sources that he was in touch not only with Norwid but also with Tepa, Kwiatkowski, Kossak, and other artists from these circles. The fact that after almost three decades the painter could recall discussions he had with Norwid on national art confirms the poet's polemical activity, which distinguished him in artistic circles and

${ }^{10}$ See: Z dziejów polskiej krytyki i teorii sztuki, vol. 2: Spór o rację bytu polskiej sztuki narodowej (1857-1891). Warszawska krytyka artystyczna (1875-1890), eds. I. Jakimowicz, A. Porębska, Warszawa 1961; Z. TROJANOWICZOWA, Ostatni spór romantyczny. Cyprian Norwid - Julian Klaczko, Warszawa 1981; Dwa głosy o sztuce. Klaczko i Norwid, ed. K. Kuczyńska, Poznań 2009.

${ }^{11}$ W. Gerson, Kartka z pamiętnika, "Tygodnik Ilustrowany” 1888, no. 288, p. 12. 
was cemented with a self-published treatise meant to "reveal, justify and defend art among Poles." [O sztuce (dla Polaków), PWsz VI, 334]

The lyre that accompanies Norwid can also refer to a certain episode from the history of Norwid's and Kossak's relationship, which was recorded in the former's short letter dated 15 September 1856 attached to the poem [Na portret generata Dembinńskiego ]"12 [On the Portrait of General Dembiński]:

Dear Juliusz

You sent me to see the portrait by Rodakowski - I send you what I saw there - please save this for later and I shall read it out loud to you, because it should be read with a Greek accent - I cannot come now because I am so embarrassed.

Until later

Cyprian

(DW XI, 117)

Both texts were found in Rodakowski's family archive by Władysław Kozicki when he was working on a monograph about the painter, and published with commentary focusing on comparative analysis of Norwid's ekphrasis and the original painting. Analysis of the poem inclined Kozicki to conclude that the poet " "saw' in it [the portrait] many things that are actually not in the painting," thus "developing in his imagination a detailed portrait of General Dembinski, one that is lofty, exalted, and accented in a Greek manner." ${ }^{\prime 3}$ This figure, made monumental and ancient-like in the poem, can be associated with another text by Norwid - O portrecie i przeznaczeniu jego [On Portraits and their Goals] - which determines the horizon of aesthetic references made by the poet. In the text written "after the death of Władysław Zamoyski" and constituting a certain kind of guide for future portraitists of the general we can find, among other things, the following advice: "All the creases and all the folds of the coat, everything together should have a thoroughly Greek calmness [...]" (PWsz VI, 479). The poem "[Na portret generała Dembińskiego]" must have made an impression on Kossak if he passed it on to the author of the portrait along with the letter. Regardless whether Norwid delivered on his promise and presented his own interpretation of the poem to the painter, taking into account its rhythm, which alludes to Greek pentameter and hexameter, the poet's words could incline the painter to form an association between him and the ancient musical instrument, the attribute of gods, heroes, and muses.

\footnotetext{
${ }^{12}$ PWsz I, 253-254.

${ }^{13}$ W. KozICKi, Wiersz Norwida o 'Generale Dembińskim 'Rodakowskiego, "Myśl Narodowa”
} 1927, no. 2, p. 30. 


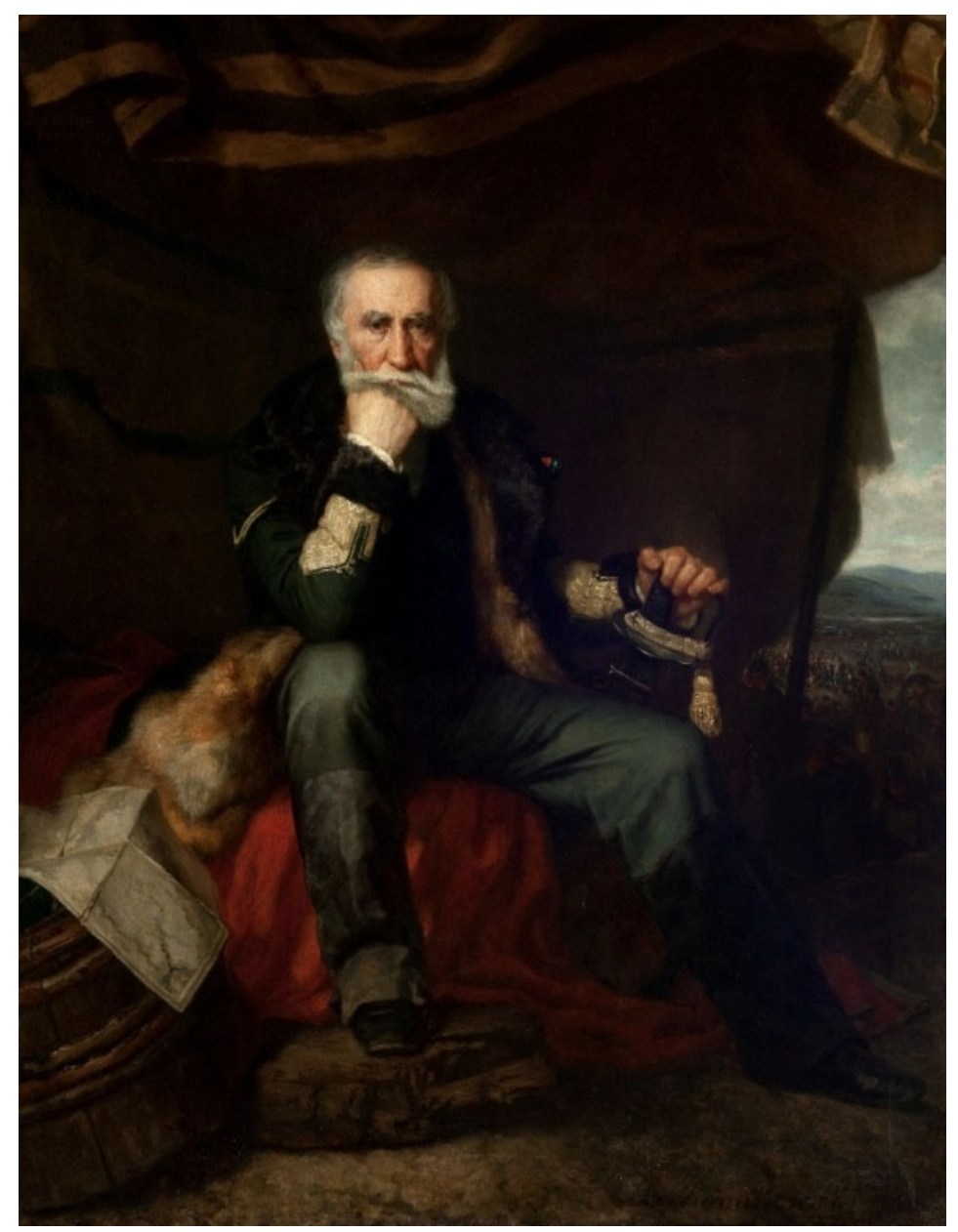

Fig. 3. Henryk Rodakowski, Portret generała Henryka Dembińskiego, 1852.

Despite its satirical formula, Orkiestra artystów constitutes an important iconographical source for Norwid-related studies, especially ones taking a biographical angle and aiming to sketch a map of the artistic circles in which the poet moved. For the "late grandsons," Norwid's life still holds many secrets. Many of its aspects have not been so far sufficiently accounted for, demanding expansion of verified knowledge, which stems largely from the simple fact that Norwid remained unacknowledged during his lifetime and his life is not as well documented in materials from the epoch as that of, say, Mickiewicz. Difficulties faced by those studying Norwid's biography are also rooted in the hugely complicated history of his many friendships and acquaintances as well as the turbulent course of his 
relationships with representatives of literary and artistic circles, with whom he would "agree to disagree" on many subjects, both personal and professional, usually at the crossroads between these two spheres of life. Although the presence of Norwid among the artists portrayed by Kossak may seem less obvious than that of other members of the orchestra, this should not come as a huge surprise. In the years 1855-1860, which the painter spent in Paris, Norwid maintained rather close relations with him, it seems, as confirmed by subtle yet important traces in his correspondence. Nevertheless, there is no evidence that this continued after Kossak returned to Poland. In this context, it seems puzzling that - after many years, towards the end of his life - Norwid sent Kossak the poem Epizod [Episode] with the following dedication: "To the great J. Kossak, painter of battles, N" (PWsz VII, 438) as well as an epistolary addendum: "To Kossak, whose address I do not know, because this is how Poles handle all their relations - like playthings!" (PWsz X, 196). ${ }^{14}$ It cannot be ruled out that the poem, devoted to the battle of Sadowa, brought back memories of the former relation with the "painter of battles," 15 with whom he probably had no contact for a longer time, as confirmed for example by the fact that he did not have his address. At the same time, the poet proved to be both determined and effective, passing the poem to the addressee through a third party.

Given the lack of source materials that would shed light on the relationship between the two artists, especially the lack of any information passed directly from Kossak, the humorous character of Orkiestra artystów does not allow us to ascertain whether the image of Norwid is in fact ironic and critical, or rather approving. The anecdotal scenes with Norwid described in Dziedzictwo do not reveal much about their relationship. Although Zofia Kossak exposed the figure of Norwid among the Parisian friends of her grandfather, it remains difficult to assess the degree to which this should be linked with the preferences of her forebear, and the extent to which it served as an expression of her own creative spirit as the author of an "apocryphal history" of the Kossak family. The writer presents Norwid from the perspective of Juliusz's young wife who - as her contemporaries confirm used to underscore the obscurity of Norwid's poetry and statements, recalling his bitter views about the emigration and calling him a recluse. Zofia recalls Norwid's frequent visits in her husband's atelier, where he felt most comfortable having the painter to himself, enjoying the conversation, silently watching Kossak work, or

${ }^{14}$ The autograph of the poet as found among Juliusz Kossak's documents (now in the National Museum in Kraków).

${ }^{15}$ Kossak painted many battle scenes, including Bitwa pod Sadowa (reproduced in 1866 in "Tygodnik Ilustrowany", no. 41). 
reciting his own poetry. Consider the following passage from Dziedzictwo, which recounts one of their meetings:

Norwid tried to convince Juliusz to paint the symbolic struggle between matter and spirit. White and green...

"Why don't you paint it yourself," the host defended himself.

"It's not my hand that's needed here. I have no sense of composition... I can see my object, but cannot transfer it to paper.

"You are overestimating my skills, Mr Cyprian. The idea is splendid, but I'm no use for it. It's a fantasy, a thing of imagination, while I'm a realist who can only paint what he sees with his own eyes..."

"You consider yourself a realist? You must be joking! Believe me, Mr Juliusz, I've never met a greater idealist than you. The world of your paintings is not prose but poetry. An embodied dream of cheerfulness. This is particularly precious because people, especially Poles, are in dire need of cheerfulness...

In the quoted passage Zofia Kossak ascribes to Norwid an opinion that significantly departs from the poet's known views on works by Kossak and other artists from his circle. It is worthwhile to recall in this context the 1863 letter to Leon Kapliński, where Norwid comments on a painting by Kapliński titled Szlachta i lud (La Noblesse et le Peuple polonais) [The Gentry and the People]: "I take delight in this because these are types - works more faithful than photographs. Kossak's watercolour is beautiful but belongs with the latter" (PWsz IX, 99; Kalendarz II, 144). According to Norwid, art is supposed to realize goals higher than mere imitation of nature because "in practicing the ideal of beauty there is a sense-of-higher-order" (O sztuce dla Polaków), while art should aspire "to express the national and universal spirit." ${ }^{" 17}$ Thus, he could not condone an aesthetics rooted in realism and naturalism, which was embraced by most painters he knew at that time. Significantly, critics and scholars would sometimes argue that Norwid attempted to influence other artists so that they would overcome the realism of their works. This was the case with the canvas Gwiazda zaranna [Morning Star] by Józef Szermentowski (1874), which presents the Mother of God with Child, seated on a heavenly throne overlooking a Polish countryside landscape. This work was argued to display Norwid's influence with regard to "mystical

${ }^{16}$ Dziedzictwo, cz. 1, pp. 189-190. The meeting at Kossak's house after Mickiewicz's burial - described in the novel (p. 149) and attended by Zan, Lenartowicz, Zaleski, and Norwid - could not have taken place in the way recounted by Kossak. The authors of Kalendarz życia i twórczości Norwida (vol. 1) have established that the poet did not participate in the funeral and only attended the Mass (p. 608).

${ }^{17}$ E. Wolicka, Przymierza łuk, [in:] Norwid a chrześcijaństwo, p. 80. 
and religious impulses." 18 Similarly, the painting Dziewczyna w kapieli (Dramat w seraju) [Girl Bathing (Drama in Seraglio)] by Pantaleon Szyndler, was shaped in its original form - as Mieczysław Geniusz claims - by Norwid, who

could not understand how one can present a picture without deeper thoughts or symbols; and since "a conjuror should retain the ability to completely change his composition" ("Ad leones"), he advised Szyndler to place figures of eastern savages with knives in the background (they were painted over later), as if fighting for the victim from the seraglio. ${ }^{19}$

Returning to Kossak's watercolour, it should be noted that there is documentation of Norwid's relations with other artists from the orchestra: Leon Kapliński, Henryk Rodakowski, Franciszek Tepa, and Tadeusz Gorecki (husband of Maria, the daughter of Adam Mickiewicz). Norwid probably also knew Teofil Kwiatkowski, a close friend of Teofil Lenartowicz. ${ }^{20}$ Most of these artists were associated with Hotel Lambert. They would meet in the salon of Marcelina Czartoryska, and their contacts bore the fruit of paintings, mainly portraits, but also works addressing national and martyrological subjects. The author of the note explaining the origin of Kossak's watercolour claims that after arriving in Paris the portrayed artists "aspired to fame and money with little success, except for Henryk Rodakowski, who had already received the Legion of Honour for his portrait of General Dembiński. [...] every Friday they would gather [...] at Kossak's and often bemoan their lack of success." Further on, he recalls that after having sent their works to Warsaw they would meet at Café de la Régence, waiting impatiently yet in vain for news from Poland about the arrival of their works. The café, located in Rue de St. Honoré, was a popular meeting place for Poles living in Paris, among other reasons because it subscribed to several Polish press titles, e.g. "Czas", "Gazeta Warszawska", and "Kurierek". ${ }^{21}$ Finally, the café was the place where Gerson delivered his address against Klaczko’s article. ${ }^{22}$

${ }^{18}$ E. Szermentowski, Norwid o Józefie Szermentowskim, "Zeszyty Kieleckie” 1 (1971), p. 74. See also my article Stracone gniazdo. Norwid-Szermentowski, "Studia Norwidiana” 34: 2016, p. 90.

19 PWsz XI, 497. See also: A. Wóscik, 'Dramat w seraju'- 'Dziewczyna w kapieli'. Wokót obrazu Pantaleona Szyndlera (1880), "Biuletyn Historii Sztuki” 2014, no. 2, pp. 223-224.

${ }^{20}$ In a letter to Kapliński, Lenartowicz mentions Norwid as a well-known person. See: M. Bолко, Korespondencja Teofila Lenartowicza z Teofilem Kwiatkowskim, (1858-1882), "Przegląd Humanistyczny" 44 (2000), no. 1-2, p. 157 (letter dated 23 February [1859]).

${ }^{21}$ T. PAdAlicA, Listy z podróży, "Gazeta Warszawska” 1857, no. 278 (22 October).

${ }^{22}$ W. Gerson, Kartka z pamiętnika, "Tygodnik Ilustrowany” 1888, no. 288, p. 12. 


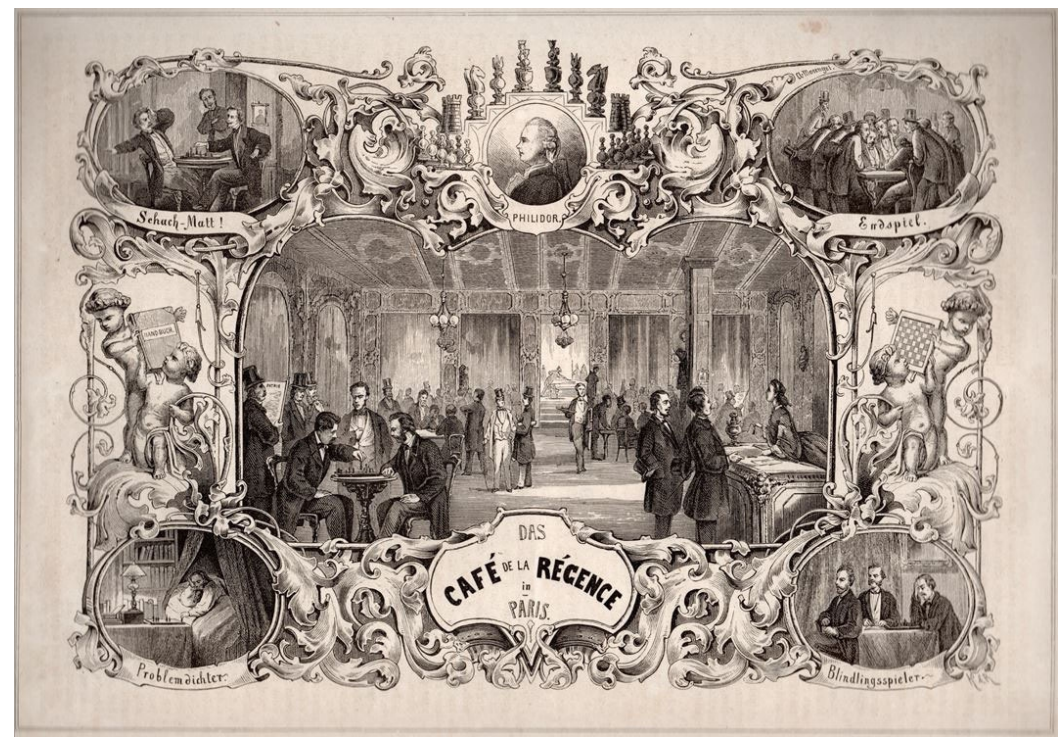

Fig. 4. Café de la Régence, 1867, woodcut, published in Die Gartenlaude

The question remains what exhibition in Warsaw could the artists gathered around Kossak send their works for. This was not settled by Anna Grochala, who draws attention in her article devoted to Orkiestra artystów to the fact that since 1858 - when the National Exhibition of Visual Art was established, paving the way before the founding of Towarzystwo Zachęty Sztuk Pięknych [Society for the Encouragement of Fine Arts] two years later - there were no permanent exhibitions of art in Warsaw. ${ }^{23}$ Activity in this field on the part of institutions (e.g. the School of Fine Arts) and private people (mainly vendors of painting materials, frame-makers, and booksellers) was very modest and limited mainly to the promotion of local artists. ${ }^{24}$ It seems that the only large show that can be considered in the context of the anecdote behind the drawing by Kossak was the aforementioned National Exhibition of Visual Art. Dariusz Konstantynów consulted press sources and the "provisional catalogue" of works gathered at the show in the second half of 1858, completing a list of works presented at the exhibition throughout the entire period of its duration. Thanks to his research we know that the show presented works by at least several "members of Kossak's orchestra," including

${ }^{23}$ A. Grochala, Juliusz Kossak jako karykaturzysta, pp. 54-55.

${ }^{24}$ A. RyszKIEwICZ, Poczatki handlu obrazami w środowisku warszawskim, Wrocław 1953; D. Konstantynów, Wystawa Krajowa Sztuk Pięknych (1858-1860). Z historii życia artystycznego Warszawy połowy XIX wieku, Warszawa 2012, pp. 7-54. 
paintings and drawings by Leon Kapliński $(1858,1859)^{25}$, Juliusz Kossak (1858, 1859, 1860), Tytus Maleszewski (1858, 1859, 1860), Henryk Rodakowski (1858, $1860)$, Leonard Straszyński $(1858,1860)$ and Franciszek Tepa $(1858,1860)$. It cannot be ruled out that Kossak's drawing was not a reaction to any specific event connected with the participation of the circle of artist friends in a specific exhibition, but constitutes a response to a number of painful experiences they would face while abroad. One thing is certain: Kossak's humorous scene offers a perfect commentary to the condition of artists "on Parisian cobbles" and to the reception of their work by the Polish public and critics.

Most painters depicted in Orkiestra artystów were hungry for "fame and money" throughout their stay in Paris, which usually lasted from several months to several years, during which they would perfect their artistic craft. They would study under Parisian masters (first choices included Horace Vernet, Leon Cognet, and Ary Scheffer), examine great works from the Louvre collection, and focus on their own practice. Some enjoyed the patronage of the aristocracy: Franciszek Tepa arrived in Paris thanks to the help of the Potocki family from Krzeszowice (we may recall the portrait of the children of Adam and Katarzyna Potoccy, which was commented on by Norwid, whose critical remarks were also shared by Scheffer $)^{26}$; Leon Kapliński could study painting thanks to the support of Seweryn Mielżyński ${ }^{27}$; and finally, Teofil Kwiatkowski was close to Prince Adam Czartoryski and his family (he made several portraits for them) ${ }^{28}$ Others would also try their luck with varying success, enquiring about loans and offering their works in exchange for financial support. The correspondence of the painters abounds in testimonies of such efforts and frequent humiliations: Kossak himself asked the Działyński family for help. In 1856, he wrote to Jan Działyński (in Kórnik): "You liked Stado przy studni [Herd by the Well] - I offer it to you, asking you to lend me three hundred francs for fourteen days" and three years later to Jadwiga Zamoyska née Działyńska, asking her to "loan two hundred francs till the end of

${ }^{25}$ The years when individual artists exhibited their works at the exhibition are provided in brackets. After: D. Konstantynów, Wystawa Krajowa Sztuk Pięknych, pp. 55-77. It is worthwhile to note the press comments indicated in the context of specific works, and a large anthology comprising the third chapter in the book Krytyka artystyczna o Wystawie Krajowej Sztuk Pięknych (ibid., pp. 139-245).

${ }^{26}$ M. DomaŃsKI, Ze studiów nad malarstwem lwowskim w XIX wieku. Franciszek Tomasz Tepa i jego krag, Lublin 1985, pp. 117-119.

${ }^{27}$ L. KrZYwKA, Sztuk-mistrz polski Leon Kapliński (1826-1873), Wrocław 1994, pp. 19-20.

${ }^{28}$ A. MelbechowsKa-Luty, Teofil Kwiatkowski (1809-1891), Wrocław-Warszawa-Kraków 1966, pp. 77-80. 
the month., ${ }^{29}$ The situation of the Kossak family must have been difficult at the time because Zofia Kossakowa would also implore with Działyński the same year:

[...] It was never as bad as it is now. [...] I have thus decided that I must [...] rescue him from this trouble and this is why I have decided to try doing so for the first time in secret [...]. All I could dream of is to borrow 3,000 roubles. [...] for no more than two years. [...] I implore you, Dear Count, forgive my lack of experience for I have so far never even considered that money can end, nor have I ever asked anyone for it, therefore please do not exacerbate my humiliation [...]. I beg you not to refuse my request and delay your answer... ${ }^{30}$

The general picture of struggles experienced by Polish émigré artists in Paris also includes the vicissitudes of Norwid preserved in his correspondence, which abounds in stories about "cartons" and drawings sent to affluent friends to cover his debts, stories of how these works would peregrinate from one potential buyer to another, endless persuasions and negotiations as well as numerous testimonies of third-party mediation in obtaining artistic commissions and winning the favour of buyers, etc. This overlapped with Norwid's unstable position in literary circles, his tempestuous track record with many fellow writers, and the constantly recurring unfavourable critical opinions regarding his poetry. The second half of the 1850s, when Kossak drew Orkiestra artystów, was a time in Norwid's life when he continuously made efforts to secure relative stabilization for himself after returning from America and facing the task to define his existence in Paris. On the one hand, he was deeply engaged with endeavours to publish his literary works, but on the other he was active in visual arts, attempting - it seems - to make this domain his main source of income. It is possible that these efforts involved seeking closer contacts with the artistic émigré circles in Paris - contacts that had never been so intense in his life. ${ }^{31}$ Traces of these relations can be identified not only in Norwid's letters, but also in his works, e.g. the poem Idacej kupić talerz pani M., [To Madame M. Going to Buy a Plate] which is addressed to the wife of Tytus Maleszewski; the above-mentioned poem Na portret generała Dembińskiego; and finally, an interesting drawing titled Odwiedziny w pracowni Leona Kaplińskiego ${ }^{32}$ [Visit in a Workshop of Leon Kapliński]. An album by Tytus Maleszewski in turn contains a sketch of Norwid's bust, accompanied by a six-

${ }^{29}$ K. OlsZAŃsKi, Juliusz Kossak, Kraków 2000, p. 69.

30 Ibid.

31 See: A. MeLbeChowSKa-LuTy, Sztukmistrz. Twórczość artystyczna i myśl o sztuce Cypriana Norwida, Warszawa 2001, pp. 54-62.

32 E. ChLeBowsKa, Norwid sztukmistrz nieznany, Lublin 2013, pp. 88-103. 
line poem by the portrayed poet himself - [Takie sa gtębie tam, na Oceanie] (PWsz I, 264) [Such Depths] - and a watercolour by Norwid titled Wnętrze karczmy flamandzkiej ${ }^{33}$ [Interior of a Flemish Inn].

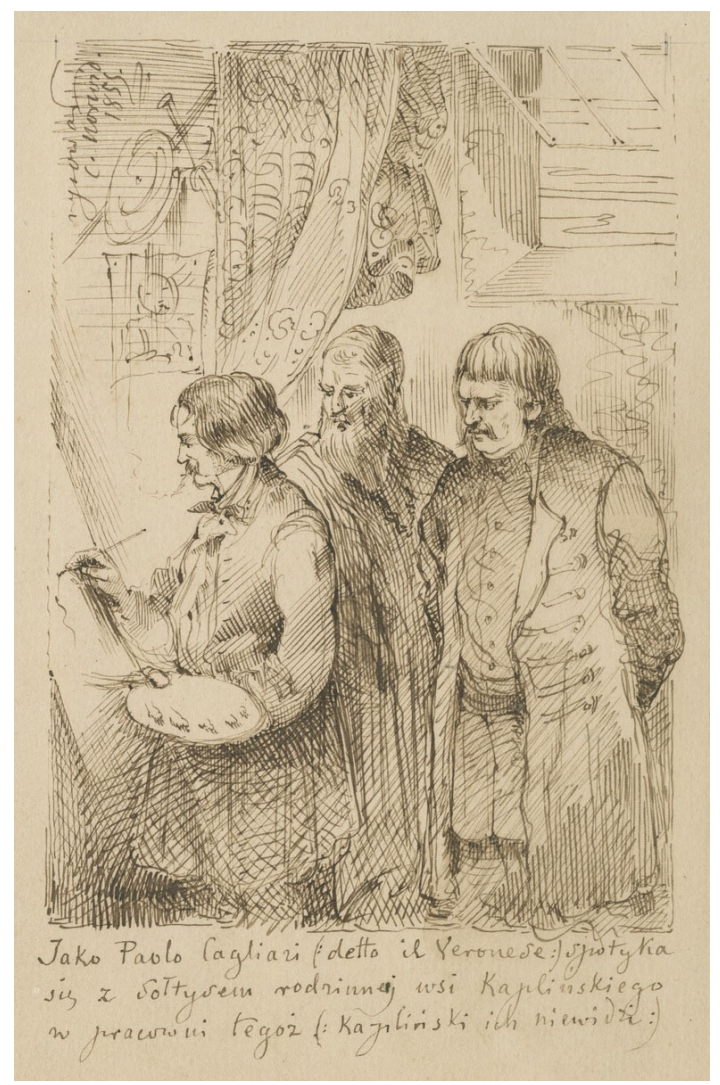

Fig. 5. C. Norwid, Odwiedziny w pracowni Leona Kaplińskiego, 1855

The above handful of remarks about Norwid's presence in the circle of painters gathered around the Paris atelier of Juliusz Kossak can be concluded with one final observation stemming directly from analysis of the humorous sketch Orkiestra artystów, which constitutes the main axis of this article. While almost all of the portrayed painters are enthusiastically focus on making music (except for the

${ }^{33}$ Maleszewski's album is preserved in the collection of the Institute of Art of the Polish Academy of Sciences. Unfortunately, the watercolour by Norwid was lost in unknown circumstances. See: A. Derwojed, Album Tytusa Maleszewskiego, "Biuletyn Historii Sztuki” 19 (1957), no. 1, pp. 61-69. For further discussion of Norwid's watercolour see: C. NorwID, Pisma zebrane, vol. A, Warszawa 1911, p. 992 (commentary by Z. Przesmycki). 
younger artists, who have "just arrived from the Academy in St. Petersburg"34 and are depicted without musical instruments), Norwid is only listening, while his lyre is lying useless next to him. This could be explained by invoking his problems with hearing, which would be sufficient reason not to play actively in the orchestra because doing so would require harmonizing with other musicians. From the perspective of Norwid studies, however, it is tempting to interpret this image as an expression of his artistic and existential situation, specifically his lone artistic journey (though made in a group of similar people) in search of goodness, truth, and beauty. The most telling and bitter testimony of this is offered by the semi-autobiographical and autotelic visual works made a decade later: Sprzedaż Pegaza [Sale of Pegasus], Sprzedawca laurów [Seller of Laurels] and Muzyk niepotrzebny [The Useless Musician]. It is possible that his close relations with Juliusz Kossak and his friends - which Norwid developed shortly after returning from America and which were rooted in the natural necessity to fit in and find recognition - were nevertheless marked by a certain distance originating in the role of an "nad-kompletowy aktor" [a superfluous actor] he ascribed to himself, or in his scepticism towards the initiative taken by his painter friends. Unlike other participants in the musical band, Norwid did not send any of his works to Warsaw in the 1850s. They were shown during exhibitions organized by Towarzystwo Zachęty Sztuk Pięknych only two decades later: in 1877 (the sketch to the oil painting Rusatka [Naiad]) and in 1879 (the watercolour Kobieta chananejska [Christ and the Canaanite Woman]). ${ }^{35}$

\section{ANNEX}

Text of the anonymous, handwritten note attached to the drawing by Kossak, written in black ink on a four-page sheet of paper:

The humour of Juliusz Kossak

When Kossak lived in Paris in the years 1855-1860 there were a dozen or so Polish painters there, who aspired to fame and money with little success, except for Henryk Rodakowski, who already received the Legion of Honour for his portrait of General Dembiński. Every Friday they would all gather at Kossak's and bemoan their failures. Kossak, who was highly valued in Warsaw, convinced them to send their works there, arguing that Józef Kenig, editor of „Gazeta Warszawska” as well as

${ }^{34}$ See: the Annex to this article.

35 J. WierCiŃSKA, Katalog prac wystawionych w Towarzystwie Zachęty Sztuk Pięknych $w$ Warszawie w latach 1860-1914, Wrocław 1969, p. 250. It is known from other sources that already in 1856 Norwid decided to send his works - the watercolour Krzysztof Kolumb and the drawing Chrystus Pan i Barabasz - to Kraków for the exhibition organized by Towarzystwo Przyjaciół Sztuk Pięknych. The former work is even discussed in the Kraków periodical "Czas" (1856, no. 105). 
a lover of art and great connoisseur of painting, shall write an exhaustive article about the Polish artists staying in Paris. They followed his advice, and began to excitedly wait for praise and fame, as promised by Kossak. With great expectations and impatience they gathered every day for coffee at Café de la Régence, which subscribed to Warsaw dailies, but they contained no mention of the paintings. Instead, they would report about Bilse's orchestra, which attracted crowds every day in the Dolina Szwajcarska park. One Friday they began complaining to Kossak that he persuaded them to send their works to Warsaw. Kossak sighed and said "well, I was mistaken and let down by Warsaw - we should have formed an orchestra." As he was saying these words, he reached out for a piece of paper and instantly sketched a chance orchestra. In the foreground, Henryk Rodakowski plays the cello [...] Kossak also included Paweł Veronez, and to punish himself for the proclaimed amateurish views on art among the Varsovians he depicted himself with a trombone. Kapliński Leon, poet and painter [?], is presented with a harp, as Derwid. The orientalist Tepa is wearing a fez and playing a tam-tam. Norwid, who was already quite deaf, sits on the side and is listening attentively. Gorecki, the son-in-law of Adam Mickiewicz, young painters who have just arrived from the Academy in St. Petersburg, including Stan. Chlebowski [...] are listening but not playing yet. The model is playing a hurdy-gurdy and singing. Faliński is calm and silent, with glasses [?], a very fine pastelist [?] is right next to him [...] playing a flute. Instead of the classicist Ingres there stands the bust of Bilse. The drawing made everyone merry and was eagerly passed from one to another, although it was completed in no more than a quarter of an hour.

\section{LIST OF FIGURES:}

Juliusz Kossak, Orkiestra artystów, [1857-1860], National Museum in Warsaw, inventory no. Rys.Pol.8900/1, photograph by Piotr Ligier / National Museum in Warsaw.

Juliusz Kossak, Orkiestra artystów, close-up (portrait of C. Norwid).

Henryk Rodakowski, Portret generała Henryka Dembińskiego, 1852, National Museum in Kraków, photograph by J. Świderski.

Café de la Régence, 1867, woodcut, published in „Die Gartenlaude”, 1867.

Cyprian Norwid, Odwiedziny w pracowni Leona Kaplińskiego, 1855, Biblioteka Naukowa PAU i PAN in Kraków, in Teofil Lenartowicz's album Umarli żywi, photograph by the library.

\section{REFERENCES}

BOJKO M., Korespondencja Teofila Lenartowicza z Teofilem Kwiatkowskim, (1858-1882), "Przegląd Humanistyczny" 44 (2000), no. 1-2, pp. 151-172.

CHELBOWSKA E., Stracone gniazdo. Norwid - Szermentowski, "Studia Norwidiana” 34: 2016, pp. 81-99.

CHLEBOWSKA E., Norwid sztukmistrz nieznany, Lublin 2013.

DOBRACZYŃSKI J., Opowieść o Juliuszu i Zofii, [in:] IDEm, Wielkość i świętość. Eseje, Warszawa 1958, pp. 275-287.

Dwa głosy o sztuce. Klaczko i Norwid, ed. K. Kuczyńska, Poznań 2009.

GERSON W., Kartka z pamiętnika, "Tygodnik Ilustrowany" 1888, no. 288, p. 12.

GROCHALA A., Juliusz Kossak jako karykaturzysta, "Spotkania z Zabytkami” 2016, no. 11-12, pp. 53-55. 
KONSTANTYNÓW D., Wystawa Krajowa Sztuk Pięknych (1858-1860). Z historii życia artystycznego Warszawy połowy XIX wieku, Warszawa 2012.

KRZYWKA L., Sztuk-mistrz polski Leon Kapliński (1826-1873), Wrocław 1994.

MASŁOWSKI M., Juliusz Kossak, Warszawa 1984.

MELBECHOWSKA-LUTY A., Sztukmistrz. Twórczość artystyczna i myśl o sztuce Cypriana Norwida, Warszawa 2001.

MROŻEK-MYSZKOWSKA J., „,Dziedzictwo”Z Zofii Kossak - próba monografii, Torun 2012.

OLSZAŃSKI K., Juliusz Kossak, second, expanded edition, Kraków 2000.

RYSZKIEWICZ A., Poczatki handlu obrazami w środowisku warszawskim, Wrocław 1953.

SZERMENTOWSKI E., Norwid o Józefie Szermentowskim, “Zeszyty Kieleckie” 1 (1971).

TROJANOWICZOWA Z., Ostatni spór romantyczny. Cyprian Norwid - Julian Klaczko, Warszawa 1981.

WIERCIŃSKA J., Katalog prac wystawionych $w$ Towarzystwie Zachęty Sztuk Pięknych $w$ Warszawie w latach 1860-1914, Wrocław 1969.

WITKIEWICZ S., Juliusz Kossak, Warszawa 1900.

WÓJCIK A., 'Dramat w seraju' - 'Dziewczyna w kapieli'. Wokół obrazu Pantaleona Szyndlera (1880), "Biuletyn Historii Sztuki” 2014, no. 2, pp. 219-240.

WÓJCIK A., Stanisław Chlebowski, „Nadworny Farbiarz Jego Sułtańskiej Mości”. Życie i twórczość, Warszawa 2016.

Z dziejów polskiej krytyki i teorii sztuki, vol. 2: Spór o rację bytu polskiej sztuki narodowej (18571891). Warszawska krytyka artystyczna (1875-1890), eds. I. Jakimowicz, A. Porębska, Warszawa 1961.

\section{$\mathrm{S} u \mathrm{~m}$ m a r y}

The article discusses the relationship between Cyprian Norwid and the circle of Polish painters gathered around Juliusz Kossak's Paris studio in the mid-nineteenth century. The starting point is Kossak's humorous drawing titled Orkiestra artystów [An Orchestra of Artists], which portrays Norwid with his back turned to the viewer and a lyre at his side, depicted among other painters, members of the orchestra, who are playing various musical instruments. On the basis of this composition, which illustrates an anecdote from the life of the exile community of Polish artists, and drawing on other accounts from the period, the article outlines the social situation of the painters, placing Norwid against this background. Emphasising the community of emigration experiences, it is thus also possible to indicate the distinctness of Norwid's situation, resulting both from his personal traits and the profile of his work, which combines literature and fine arts and is strongly rooted in theoretical reflection.

Keywords: Cyprian Norwid; Juliusz Kossak; Polish drawing; Paris; Café de la Régence

Edyta Chlebowska, PhD is an art historian working at the Centre for the Study of Cyprian Norwid's Literature at the John Paul II Catholic University in Lublin. Address: Chopina 27, room 550, 20-023 Lublin; e-mail: edytowo@gmail.com. 